\title{
(2) OPEN ACCESS \\ Early-life risk factors for reversible and irreversible airflow limitation in young adults: findings from the BAMSE birth cohort
}

\author{
Gang Wang, ${ }^{1,2,3}$ Inger Kull, ${ }^{2,3,4}$ Anna Bergström, ${ }^{2,5}$ Jenny Hallberg, ${ }^{3,4}$ \\ Petra Um Bergström, ${ }^{3,4}$ Stefano Guerra (1) ${ }^{6,7}$ Goran Pershagen, ${ }^{2,5}$ Olena Gruzieva, ${ }^{2,5}$ \\ Marianne van Hage, ${ }^{8}$ Antonios Georgelis, ${ }^{2,5}$ Christer Janson (1) , ${ }^{9}$ Anders Lindén, ${ }^{2,10}$ \\ Erik Melén 2,3,4
}

\begin{abstract}
- Additional material is published online only. To view, please visit the journal online (http://dx.doi.org/10.1136/ thoraxjnl-2020-215884).
\end{abstract}

For numbered affiliations see end of article.

Correspondence to Dr Erik Melén, Department of Clinical Science and Education Södersjukhuset, Karolinska Institutet, Stockholm 118 83, Sweden; erik.melen@ki.se

Received 28 July 2020 Revised 13 October 2020 Accepted 14 October 2020 Published Online First 12 November 2020

Check for updates

(C) Author(s) (or their employer(s)) 2021. Re-use permitted under CC BY. Published by BMJ.

To cite: Wang G, Kull I, Bergström A, et al. Thorax 2021;76:503-507.

\section{ABSTRACT}

We aimed to determine prevalence and early-life risk factors for reversible and irreversible airflow limitation in young adults from the general population. Among young adults in their 20s, the prevalence was 5.3\% for reversible airflow limitation and $2.0 \%$ for irreversible airflow limitation. While parental asthma was the only risk factor for development of reversible airflow limitation, the risk factors for development of irreversible airflow limitation were current asthma, childhood respiratory tract infections and asthma, and exposure to air pollution.

It has been shown that impaired lung function in children and young adults is associated with an increased risk of chronic obstructive pulmonary disease (COPD) later in life. ${ }^{12}$ Recently, airflow limitation defined as pre-bronchodilator (BD) forced expiratory volume in $1 \mathrm{~s}\left(\mathrm{FEV}_{1}\right) /$ forced vital capacity (FVC) below the lower limit of normal (LLN) was observed in 4\% of adults aged 20-29 years who have less than 5 pack-years tobacco load, and up to $7 \%$ in participants who have 5 pack-years or more tobacco load. ${ }^{3}$ However, few published studies addressed reversible airflow limitation and irreversible airflow limitation in young adults. Given this, we aimed to determine the prevalence and early-life risk factors for reversible airflow limitation and irreversible airflow limitation in young adults from the general population.

A total of 1932 participants in the populationbased birth cohort Barn/Children, Allergy, Milieu, Stockholm, Epidemiology (BAMSE) performed valid pre-BD and post-BD lung function measurements at the 24-year follow-up. ${ }^{45}$ Lung function was tested according to American Thoracic Society (ATS)/European Respiratory Society (ERS) criteria as previously described. ${ }^{6}$ Post-BD lung function was tested $15 \mathrm{~min}$ after administration of $400 \mu \mathrm{g}$ salbutamol. 'Normal lung function' was defined as pre-BD and post-BD $\mathrm{FEV}_{1} / \mathrm{FVC} \geq \mathrm{LLN}^{7}$ ' 'Reversible airflow limitation' as pre-BD $\mathrm{FEV}_{1} / \mathrm{FVC}<\mathrm{LLN}$ but post-BD FEV1/ $\mathrm{FVC} \geq \mathrm{LLN}$, and 'Irreversible airflow limitation' as pre-BD and post-BD $\mathrm{FEV}_{1} / \mathrm{FVC}<\mathrm{LLN}$. ORs and 95\% CIs for risk factors in relation to reversible airflow limitation or irreversible airflow limitation, selected based on previous literature and availability in BAMSE, were estimated using multivariable logistic regression in R (V.4.0.2).
The prevalence of reversible airflow limitation was $5.3 \%(n=103,95 \%$ CI $4.3 \%$ to $6.3 \%)$, and irreversible airflow limitation $2.0 \% \quad(n=39$, $95 \%$ CI $1.4 \%$ to $2.6 \%$ ) at the 24 -year follow-up. Forty-nine per cent reported respiratory symptoms in those with irreversible airflow limitation compared with $25 \%$ in those with normal lung function (table 1). In addition, participants in the irreversible airflow limitation group also reported more cough, but not more mucus production, during winter mornings. Besides, there were reports of more respiratory symptoms (defined as troublesome breasing, chest tightness or wheezing) and pneumonia events during the last 12 months in the irreversible airflow limitation group. However, no such differences were observed for the groups with reversible airflow limitation and normal lung function. There were lower pre-BD FEV 1 and post-BD $\mathrm{FEV}_{1}$ (by design, online supplemental table E1), higher pre-BD FVC and post-BD FVC, and higher reversibility (change in $\mathrm{FEV}_{1}$ and change in $\mathrm{FEV}_{1} \%$ baseline) in the reversible and irreversible airflow limitation groups compared with the group with normal lung function. Fifteen and $2.9 \%$ of participants with irreversible and reversible airflow limitation had post-BD $\mathrm{FEV}_{1}$ lower than LLN, respectively, compared with $1.5 \%$ in the group with normal lung function (online supplemental table E1). No substantial difference was observed for other variables, except higher body mass index (BMI) was observed in participants with irreversible airflow limitation (table 1). In logistic regression models adjusted for age, gender and BMI, several indicators of early life infections and respiratory diseases, environmental exposures and current asthma were risk factors associated with irreversible airflow limitation (table 2). In mutually adjusted analyses, respiratory syncytial virus (RSV) infection/pneumonia during infancy, nitrogen oxide $\left(\mathrm{NO}_{\mathrm{x}}\right)$ exposure during age $0-1$ years, childhood asthma during age $0-4$ years and current asthma were independent risk factors for irreversible airflow limitation (table 3). For reversible airflow limitation, parental asthma and childhood asthma during age $0-4$ and $8-12$ years, NO exposure during age $8-12$ years and current asthma were associated factors. In mutually adjusted analyses, parental asthma alone was an independent risk factor for reversible airflow limitation. 
Table 1 Characteristics of cohort participants with Irreversible airflow limitation or Reversible airflow limitation and normal lung function*

\begin{tabular}{|c|c|c|c|c|c|}
\hline & \multirow[b]{2}{*}{$\begin{array}{l}\text { Irreversible airflow } \\
\text { limitation }(\mathrm{N}=39)\end{array}$} & \multirow[b]{2}{*}{$\begin{array}{l}\text { Reversible airflow } \\
\text { limitation }(\mathrm{N}=103)\end{array}$} & \multirow[b]{2}{*}{$\begin{array}{l}\text { Normal lung function } \\
(\mathrm{N}=1790)\end{array}$} & \multicolumn{2}{|l|}{$P$ value } \\
\hline & & & & $\begin{array}{l}\text { Irreversible airflow } \\
\text { limitation versus } \\
\text { normal lung function }\end{array}$ & $\begin{array}{l}\text { Reversible airflow } \\
\text { limitation versus } \\
\text { normal lung } \\
\text { function }\end{array}$ \\
\hline Age, years, mean (SD) & $22.4(0.5)$ & $22.4(0.5)$ & $22.4(0.5)$ & 0.7387 & 0.5593 \\
\hline Sex, female, n (\%) & $19(48.7)$ & $58(56.3)$ & $1042(58.2)$ & 0.2346 & 0.7037 \\
\hline $\mathrm{BMI}, \mathrm{kg} / \mathrm{m}^{2}$, mean (SD) & $24.9(5.9)$ & $23.2(3.0)$ & $23.1(3.8)$ & 0.0060 & 0.9549 \\
\hline Education, n (\%) & & & & 0.1506 & 0.7524 \\
\hline Secondary school & $20(51.3)$ & $62(60.2)$ & $1118(62.6)$ & & \\
\hline High school & $9(23.1)$ & $23(22.3)$ & $405(22.7)$ & & \\
\hline University & $10(25.6)$ & $18(17.5)$ & $264(14.8)$ & & \\
\hline Active childhood smoking, $\mathrm{n}(\%)$ & & & & 0.2804 & 0.8711 \\
\hline Never & $23(59.0)$ & $70(68.0)$ & $1200(67.2)$ & & \\
\hline Ever & $16(41.0)$ & $33(32.0)$ & $586(32.8)$ & & \\
\hline Tobacco consumption (pack-years), median (IQR) & $1.1(0.1$ to 1.6$)$ & $1.0(0.1$ to 2.3$)$ & $0.4(0.1$ to 1.7$)$ & $0.4504+$ & $0.3609+$ \\
\hline \multicolumn{6}{|l|}{ Respiratory health events } \\
\hline Cough during winter morning, $\mathrm{n}(\%)$ & $9(23.1)$ & $11(10.8)$ & $139(7.9)$ & 0.0006 & 0.3686 \\
\hline Mucus production during winter morning, $\mathrm{n}(\%)$ & $6(15.8)$ & $18(17.8)$ & $257(14.6)$ & 0.8319 & 0.4999 \\
\hline Respiratory symptoms, n (\%) & $19(48.7)$ & $34(33.0)$ & $451(25.2)$ & 0.0009 & 0.0791 \\
\hline Pneumonia in the last 12 months, $\mathrm{n}(\%)$ & $4(10.3)$ & $3(3.0)$ & $44(2.5)$ & $0.0183 \ddagger$ & $0.7387 \ddagger$ \\
\hline \multicolumn{6}{|l|}{ Sensitisation at age 24 years } \\
\hline Sensitisation to airborne allergens, $\mathrm{n}(\%)$ & $18(46.2)$ & $36(35.6)$ & $767(43.5)$ & 0.7414 & 0.1207 \\
\hline Sensitisation to food allergens, $n$ (\%) & $5(12.8)$ & $10(9.9)$ & $153(8.7)$ & $0.3826 \ddagger$ & 0.6736 \\
\hline \multicolumn{6}{|l|}{ Reversibility test } \\
\hline Change in $\mathrm{FEV}_{1}, \mathrm{ml}$, median (IQR) & 243 (156 to 360$)$ & 273 (192 to 373 ) & 111 (50 to 185$)$ & $<0.0001 \dagger$ & $<0.0001 \dagger$ \\
\hline Change in $\mathrm{FEV}_{1} \%$ baseline, $\%$, median (IQR) & 7.3 (4.2 to 10.2$)$ & $7.7(5.1$ to 9.9$)$ & $2.8(1.3$ to 4.6$)$ & $<0.0001 \dagger$ & $<0.0001 \dagger$ \\
\hline \multicolumn{6}{|l|}{ Blood different cell count, $\times 10^{9} / \mathrm{L}$} \\
\hline Neutrophils, mean (SD) & $3.86(1.5)$ & $3.51(1.37)$ & $3.71(1.4)$ & 0.5358 & 0.1734 \\
\hline Eosinophils, median (IQR) & $0.10(0.1$ to 0.2$)$ & $0.10(0.0$ to 0.2$)$ & $0.10(0.0$ to 0.2$)$ & $0.0529 \dagger$ & $0.7534 \dagger$ \\
\hline
\end{tabular}

${ }^{*}$ Details about the definitions of health outcomes and covariates are provided in the online supplemental file.

tBased on Kruskal-Wallis rank sum test.

‡Based on Fisher's exact test.

$\mathrm{BMI}$, body mass index; $\mathrm{FEV}_{1}$, forced expiratory volume in $1 \mathrm{~s}$.

In summary, we found the overall prevalence of reversible and irreversible airflow limitation to be rather high $(5.3 \%$ and $2.0 \%$, respectively), considering the young age of the participants. Individuals with irreversible airflow limitation more often reported current respiratory symptoms and pneumonia compared with those with normal lung function. Besides, more severe lung function impairments were observed in individuals with irreversible airflow limitation. Thus, there was a substantial disease burden in participants with irreversible airflow limitation. Results from previous epidemiology studies demonstrate that abnormal lung development plays an important role in the development of COPD and a substantial proportion of subjects diagnosed with COPD after age 50 could be traced back to a relatively low peak lung function in their 20s. ${ }^{8}$ Our current findings extend those results by demonstrating that irreversible airflow limitation is present in young adults. This was observed despite most of them being nonsmokers, and ever-smokers having smoked on average less than one pack-year. Moreover, although only $28 \%$ of the irreversible airflow limitation subjects were classified as having current asthma, enhanced airway reversibility was observed, which suggests that, at this early stage of disease, reversibility is to some extent present.
In our study, early-life respiratory infections (RSV infection/ pneumonia) and exposure to air pollutants, as well as childhood asthma, were identified as strong risk factors for irreversible airflow limitation. Given that air pollution levels in Stockholm are comparatively low by international standards, this makes the current findings alarming in a global context. Early risk factors may influence lung function development in a negative manner that will likely track with age, ${ }^{9}$ and in the current study, these early lung insults were even stronger risk factors for irreversible airflow limitation than smoking exposure in childhood and active smoking in adolescence. Thus, early-life exposure to air pollutants emerges as an important risk factor, known to be associated with not only lung development,${ }^{6}$ but also with childhood pneumonia ${ }^{10}$ and asthma. ${ }^{11}$

In our study, the only identified independent risk factor for reversible airflow limitation was parental asthma, which suggests that the reversible airflow limitation phenotype relates primarily to asthma heredity, rather than to impaired lung development.

Our study has the drawback of a relatively small irreversible airflow limitation sample size and only around $50 \%$ of the initial 4089 cohort participants provided pre-BD and post-BD 


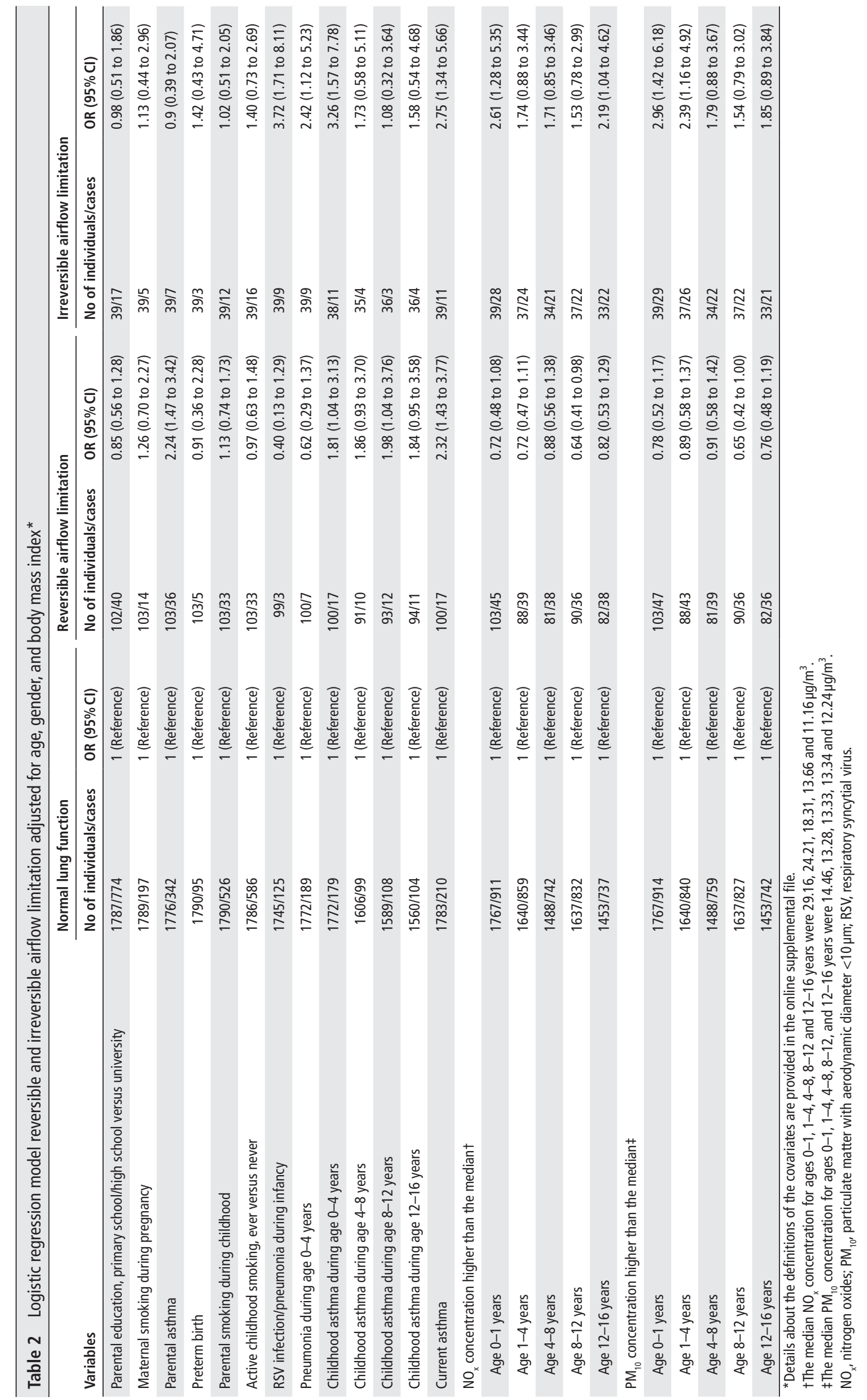


Table 3 Mutually adjusted analyses for reversible and irreversible airflow limitation which included age, gender, body mass index and other related factors*

\begin{tabular}{|c|c|c|c|c|}
\hline \multirow[b]{2}{*}{ Variables } & \multicolumn{2}{|l|}{ Normal lung function } & \multicolumn{2}{|c|}{ Irreversible airflow limitation } \\
\hline & No of individuals/cases & OR $(95 \% \mathrm{Cl})$ & No of individuals/cases & OR $(95 \% \mathrm{Cl})$ \\
\hline $\mathrm{NO}_{x}$ concentration during age $0-1$ yearst, high versus low & $1261 / 651$ & 1 (Reference) & $29 / 22$ & 3.08 (1.11 to 8.51$)$ \\
\hline $\mathrm{NO}_{x}$ concentration during age $12-16$ yearst, high versus low & $1261 / 637$ & 1 (Reference) & $29 / 21$ & $2.12(0.82$ to 5.46$)$ \\
\hline RSV infection/pneumonia during infancy & $1261 / 84$ & 1 (Reference) & $29 / 8$ & 3.59 (1.41 to 9.14$)$ \\
\hline Childhood asthma during age $0-4$ years & $1261 / 127$ & 1 (Reference) & $29 / 8$ & 3.36 (1.22 to 9.24$)$ \\
\hline Childhood asthma during age $4-8$ years & $1261 / 78$ & 1 (Reference) & $29 / 2$ & $0.32(0.06$ to 1.81$)$ \\
\hline Childhood asthma during age $8-12$ years & $1261 / 82$ & 1 (Reference) & $29 / 1$ & $0.16(0.02$ to 1.43$)$ \\
\hline Childhood asthma during age $12-16$ years & $1261 / 78$ & 1 (Reference) & $29 / 3$ & $1.31(0.32$ to 5.44$)$ \\
\hline Current asthma & $1261 / 144$ & 1 (Reference) & $29 / 7$ & 3.51 (1.22 to 10.15$)$ \\
\hline Variables & \multicolumn{2}{|l|}{ Normal lung function } & \multicolumn{2}{|c|}{ Reversible airflow limitation } \\
\hline Parental asthma & $1317 / 253$ & 1 (Reference) & $77 / 28$ & 2.17 (1.31 to 3.58$)$ \\
\hline $\mathrm{NO}_{x}$ concentration during age 8-12 yearst, high versus low & $1317 / 654$ & 1 (Reference) & $77 / 34$ & $0.82(0.51$ to 1.32$)$ \\
\hline Childhood asthma during age $0-4$ years & $1317 / 137$ & 1 (Reference) & $77 / 14$ & 1.37 (0.68 to 2.75$)$ \\
\hline Childhood asthma during age $4-8$ years & $1317 / 84$ & 1 (Reference) & $77 / 9$ & $0.92(0.36$ to 2.34$)$ \\
\hline Childhood asthma during age $8-12$ years & $1317 / 88$ & 1 (Reference) & $77 / 10$ & 1.22 (0.50 to 2.97$)$ \\
\hline Childhood asthma during age $12-16$ years & $1317 / 87$ & 1 (Reference) & $77 / 10$ & $1.21(0.51$ to 2.86$)$ \\
\hline Current asthma & $1317 / 154$ & 1 (Reference) & $77 / 16$ & $1.49(0.72$ to 3.11$)$ \\
\hline
\end{tabular}

*Details about the definitions of covariates are provided in the online supplemental file.

tThe median $\mathrm{NO}_{\mathrm{x}}$ concentration for ages $0-1,8-12$ and $12-16$ years were $29.16,13.66$ and $11.16 \mu \mathrm{g} / \mathrm{m}^{3}$.

$\mathrm{NO}_{x^{\prime}}$, nitrogen oxides; RSV, respiratory syncytial virus.

spirometry data at 24 years of age. However, no selection bias could be identified so far in the BAMSE cohort. ${ }^{4}$

In conclusion, this study forwards evidence that among young adults in their 20s, the prevalence was $5.3 \%$ for reversible airflow limitation and $2.0 \%$ for irreversible airflow limitation. While parental asthma emerges as the only risk factor for development of reversible airflow limitation, the risk factors for development of irreversible airflow limitation were current asthma, childhood respiratory tract infections and asthma, and exposure to air pollution.

\section{Author affiliations}

'Department of Integrated Traditional Chinese and Western Medicine, West China Hospital, Sichuan University, Chengdu, Sichuan, China

${ }^{2}$ Institute of Environmental Medicine, Karolinska Institutet, Stockholm, Sweden ${ }^{3}$ Department of Clinical Science and Education, Södersjukhuset, Karolinska Institutet, Stockholm, Sweden

${ }^{4}$ Sachs' Children's Hospital, Stockholm, Sweden

${ }^{5}$ Centre for Occupational and Environmental Medicine, Region Stockholm, Stockholm, Sweden

${ }^{6}$ Asthma and Airway Disease Research Center, The University of Arizona, Tucson, Arizona, USA

${ }^{7}$ ISGLOBAL, Barcelona, Spain

${ }^{8}$ Medicine Solna, Division of Immunology and Allergy, Karolinska Institutet, Stockholm, Sweden

${ }^{9}$ Department of Medical Sciences: Respiratory, Allergy and Sleep Research, Uppsala University, Uppsala, Sweden

${ }^{10}$ Department of Respiratory Medicine and Allergy, Karolinska University Hospital, Stockholm, Sweden

Contributors $\mathrm{JH}, \mathrm{AL}$ and EM designed the study and outlined the contents of the manuscript. GW was responsible for the practical conduct of the study, including the planning, coordination and analyzes of the data, and the writing the manuscript under the supervision by EM. JH had overall responsibility for the lung function measurements at 24 years of age. GP and $O G$ had overall responsibility for the air pollution data. PUB, CJ, MvH, AG, AB, SG and IK revised the work critically for the content. All authors contributed to the interpretation of the data and approved the final manuscript prior to its submission.

Funding This study was supported by grants from the Swedish Research Council, the Swedish Research Council for Health, Working Life and Welfare, Formas, the
Swedish Heart-Lung Foundation, the European Research Council (TRIBAL, grant agreement 757919), Strategic Research Area (SFO) Epidemiology, Karolinska Institutet and Region Stockholm (ALF project, and for cohort and database maintenance), Swedish Asthma and Allergy Association's Research Foundation. The Cancer and Allergy Foundation and the Swedish Association for Allergology (through the Major research grant sponsored by Novartis, Sanofi, Mylan, GSK, Astra Zeneca). The King Gustaf V 80th Birthday Foundation. The Hesselman Foundation. Thermo Fisher Scientific (Uppsala, Sweden) provided reagents for IgE analyses. GW is sponsored by the China Scholarship Council (CSC, File No. 201906240227).

Disclaimer The funders had no role in designing the project or interpretation of data.

Competing interests EM reports personal fees from Sanofi, Chiesi and AstraZeneca, outside the submitted work.

Patient consent for publication Not required.

Provenance and peer review Not commissioned; externally peer reviewed.

Open access This is an open access article distributed in accordance with the Creative Commons Attribution 4.0 Unported (CC BY 4.0) license, which permits others to copy, redistribute, remix, transform and build upon this work for any purpose, provided the original work is properly cited, a link to the licence is given, and indication of whether changes were made. See: https://creativecommons.org/ licenses/by/4.0/.

\section{ORCID iDs}

Stefano Guerra http://orcid.org/0000-0001-7218-3246

Christer Janson http://orcid.org/0000-0001-5093-6980

\section{REFERENCES}

1 Agustí A, Faner R. Copd beyond smoking: new paradigm, novel opportunities. Lancet Respir Med 2018;6:324-6.

2 Melén E, Guerra S, Hallberg J, et al. Linking COPD epidemiology with pediatric asthma care: implications for the patient and the physician. Pediatr Allergy Immunol 2019;30:589-97.

3 Çolak Y, Afzal S, Nordestgaard BG, et al. Prevalence, characteristics, and prognosis of early chronic obstructive pulmonary disease. The Copenhagen general population study. Am J Respir Crit Care Med 2020;201:671-80.

4 Melén E, Bergström A, Kull I, et al. Male sex is strongly associated with IgEsensitization to airborne but not food allergens: results up to age 24 years from the BAMSE birth cohort. Clin Trans/ Allergy 2020;10:15.

5 Wang G, Hallberg J, Bergström PU, et al. Assessment of chronic bronchitis and risk factors in young adults: results from BAMSE. Eur Respir I 2020. 
6 Schultz ES, Hallberg J, Bellander T, et al. Early-Life exposure to traffic-related air pollution and lung function in adolescence. Am J Respir Crit Care Med 2016;193:171-7.

7 Quanjer PH, Stanojevic S, Cole TJ, et al. Multi-Ethnic reference values for spirometry for the 3-95-yr age range: the global lung function 2012 equations. Eur Respir J 2012:40:1324-43.

8 Bui DS, Lodge CJ, Burgess JA, et al. Childhood predictors of lung function trajectories and future COPD risk: a prospective cohort study from the first to the sixth decade of life. Lancet Respir Med 2018;6:535-44.
9 Stern DA, Morgan WJ, Wright AL, et al. Poor airway function in early infancy and lung function by age 22 years: a non-selective longitudinal cohort study. Lancet 2007;370:758-64.

10 Darrow $L A$, Klein $M$, Flanders WD, et al. Air pollution and acute respiratory infections among children 0-4 years of age: an 18-year time-series study. Am J Epidemiol 2014:180:968-77.

11 Gehring U, Wijga AH, Hoek G, et al. Exposure to air pollution and development of asthma and rhinoconjunctivitis throughout childhood and adolescence: a populationbased birth cohort study. Lancet Respir Med 2015;3:933-42. 